BOGUSŁAW ŚLIWERSKI

Forum Pedagogiczne

Wydział Pedagogiczny

$2015 / 2$

Chrześcijańska Akademia Teologiczna

Warszawa

\title{
MIEJSCE SYSTEMU WYCHOWANIA PREWENCYJNEGO WEDŁUG JANA BOSKO WE WSPÓŁCZESNEJ SYSTEMATYCE MYŚLI PEDAGOGICZNEJ
}

\author{
„Obraz współczesności musi się różnić od wypracowanego \\ przez całe pokolenia obrazu przeszłości" \\ (Bogdan Nawroczyński, Wspótczesne prądy pedagogiczne, 1987, s. 483).
}

Streszczenie: Przedmiotem analizy jest miejsce pedagogii św. Jana Bosko we współczesnej systematyce myśli pedagogicznej oraz w leksykografii nauk o wychowaniu. Nie zajmuję się recepcją i aktualizacją systemu wychowawczego św. Jana Bosko w obrębie pedagogiki katolickiej, gdyż jest to zadanie dla księży, sióstr i świeckich naukowców bezpośrednio z nią związanych. Zwolennicy tej pedagogiki powinni mieć świadomość tego, w jakim zakresie jest obecna, reinterpretowana, marginalizowana lub wypaczana koncepcja przedstawiciela jednego z wciąz - moim zdaniem - niedocenianych podejść do systemu wychowania, który nie tylko nie stracił na aktualności, ale znacznie wyprzedził swoją epokę. Pedagodzy myśli chrześcijańskiej, a pedagogiki katolickiej w szczególności, są zobowiązani z jednej strony do pielęgnowania jej we własnym środowisku, ale z drugiej strony także do włączania jej do obecnych klasyfikacji, typologii, leksykonów i rozwiązań praktycznych. Mimo że pedagogia uprzedzająca św. Jana Bosko liczy sobie już prawie dwa wieki, to jednak dopiero teraz, w kapitalizmie ponowoczesnym, może stać się jednym z najbardziej efektywnych podejść do pracy z osobami wykluczanymi, już wykluczonymi czy zagrożonymi wykluczeniem społecznym.

Słowa kluczowe: pedagogika chrześcijańska, pedagogika religii, pedagogika katolicka, system wychowawczy, wykluczenie społeczne, profilaktyka, socjalizacja, wychowanie uprzedzające, pedagogika ulicy, leksykografia pedagogiczna, biografistyka pedagogiczna

Każdy, kto chce podjąć problem rekonstrukcji myśli pedagogicznej przedstawiciela jednej z jej koncepcji, pedagogii czy systemu wychowania, musi sięgnąć do jej dziejów: genezy i ewolucji. Pedagogia uprzedzająca św. Jana Bosko ma już prawie dwa wieki. Nie można jednak jej istnienia liczyć od chwili narodzin twórcy, a zarazem organizatora instytucjonalnych czy środowiskowych form osadzenia w praktyce 
opiekuńczo-wychowawczej i dydaktycznej. Ustalenie, kiedy położono podwaliny pod prewencyjny system pracy z dziećmi i młodzieżą tego wybitnego włoskiego duchownego i zarazem pedagoga, to zadanie dla historyków. Ogólnopolska Konferencja Naukowa Wydziału Nauk Pedagogicznych Uniwersytetu Kardynała Stefana Wyszyńskiego w Warszawie została zorganizowana przez Katedrę Historii Wychowania i Dziejów Oświaty, ale także Wydział Teologiczny UKSW - Instytut Teologii Praktycznej nie tylko po to, żeby uczcić 20o-lecie urodzin św. Jana Bosko, ale także by przeprowadzić debatę na temat tego, jak dzisiaj środowiska salezjańskie radzą sobie z wyzwaniami ponowoczesnego świata. Czy rzeczywiście uprzedzający system wychowawczy Jana Bosko jest aktualny, ponadczasowy? Czy możemy mówić o jego (nie)obecności w naukach pedagogicznych w naszym kraju?

Nie będę zajmował się wewnętrzną recepcją i aktualizacją systemu wychowawczego św. Jana Bosko, gdyż jest to zadanie dla księży, sióstr i świeckich naukowców związanych bezpośrednio z pedagogiką salezjańską. Znakomicie ujęli je też w swoich studiach opublikowanych w zbiorowym dziele poświęconym pedagogii katolickich zgromadzeń zakonnych ks. Kazimierz Misiaszek SDB i s. Halina Wrońska CMW (Misiaszek 2012; Wrońska 2012). Zapewne też debata, w której uczestniczę, przyniesie nowe aspekty i wyniki badań w tym zakresie. Interesuje mnie szerszy kontekst istnienia tej pedagogii w systematyce współczesnej myśli nauk o wychowaniu, gdyż nie ulega wątpliwości, że dzieło San Giovanni Melchiorre Bosco zaczęło szerzej promieniować na praktyczną pedagogikę opiekuńczo-wychowawczą i szkolną dopiero po II wojnie światowej, kiedy to najpierw we Włoszech, a następnie w innych krajach naszego kontynentu wzrosło zainteresowanie nią i nastąpił systematyczny rozwój szkolnictwa salezjańskiego (z pominięciem w naszym kraju okresu PRL-u). Nie bez znaczenia dla tego procesu był także Sobór Watykański II, który zalecał zakonom i zgromadzeniom zakonnym dokonanie swoistej aktualizacji dotychczasowych praktyk wychowawczych do nowej sytuacji społeczno-politycznej, kulturowej i edukacyjnej.

\section{Pedagogia św. Jana Bosko w leksykografii pedagogicznej XX i XXI wieku}

Badacze w każdej epoce sięgają zazwyczaj w swoich dociekaniach naukowych do publikacji mających charakter leksykograficzny, bowiem stanowią one nowoczesne kompendium wiedzy pedagogicznej nie tylko prezentujące klasyków myśli i systemów wychowawczych, ale także przybliżające w syntetyczny sposób ich idee wychowawcze, pojęcia, koncepcje, założenia czy rozwiązania praktyczne. W hasłach biograficznych znajdujemy także odniesienia do źródłowej i najnowszej literatury przedmiotu, a nawet do znaczących dla kategorii baz danych. Z jednej strony, redaktorzy takich opracowań odwołują się do historii, z drugiej zaś, dobierając hasła i konstruując ich treść, sięgają do własnych doświadczeń naukowych i dydaktycznych. 
W polskiej leksykografii współczesnej hasło biograficzne „Bosko (Bosco) Jan” występuje jedynie w dwóch opracowaniach: w Nowym słowniku pedagogicznym Wincentego Okonia (Okoń 2004, s. 52) oraz w leksykonie Pedagogika, wydanym pod redakcją Bogusława Milerskiego i Bogusława Śliwerskiego (Milerski, Śliwerski 2000, s. 31), natomiast zostało pominięte w wydanym w 2009 roku Słowniku pedagogicznym Czesława i Małgorzaty Kupisiewiczów (C. Kupisiewicz, M. Kupisiewicz 2009). Odnotowuję zarazem, że w wydanym przez Czesława Kupisiewicza i Irenę Wojnar dwutomowym dziele leksykograficznym Myśliciele - o wychowaniu, pomyślanym jako prezentacja biogramów pedagogów wszech czasów, wśród których znajdują się zarówno przedstawiciele filozofii wychowania, ,jak i badacze kształtujący myśl oraz praktykę pedagogiczną naszych czasów” (Kupisiewicz, Wojnar 1996, s. 5), nie ma św. Jana Bosko. To oznacza, że środowisko salezjańskie, jak i szeroko pojmowanej pedagogiki katolickiej, powinno zabiegać o to, by UNESCO - które było inicjatorem przybliżenia w przekładach na wiele języków świata poglądów klasyków myśli i praktyki pedagogicznej - wprowadziło do nowej edycji także system wychowawczy interesującego nas nie tylko z racji 200-lecia urodzin świętego.

O ile nie dziwi mnie nieobecność pedagogii Jana Bosko w Encyklopedii pedagogicznej marksistowskiego pedagoga Wojciecha Pomykały, który wydał ją w 1997 roku chyba dla przykrycia swojej socjalistycznej proweniencji, twierdząc, że rzekomo odzwierciedla pluralistyczny charakter pedagogiki (Pomykało 1997), o tyle dużym zaskoczeniem jest dla mnie zupełna nieobecność tej pedagogii w Leksykonie pedagogiki religii pod redakcją ks. Cypriana Rogowskiego (Rogowski 2007). Skoro pierwsze tego typu wydanie w XXI wieku zostało poświęcone nowej dyscyplinie naukowej, jaka ukształtowała się i rozwinęła na początku ubiegłego stulecia w krajach niemieckojęzycznych, to nie powinno pomijać systemu wychowawczego Jana Bosko ani jego twórcy. Nie może być tu usprawiedliwieniem fakt, że redaktor leksykonu skoncentrował się przede wszystkim na kategoriach pojęciowych i biografiach występujących w tego typu literaturze obszaru języka niemieckiego, gdyż zamiast wypełnić istniejącą lukę, sam ją tworzy. Niedopatrzenie to jest tym bardziej istotne, że ów leksykon jest adresowany do teologów, religiologów, filozofów, pedagogów, socjologów, psychologów i przedstawicieli innych dyscyplin humanistycznych.

Niestety, nie ma też biogramu poświęconego św. Janowi Bosko w Podręcznej encyklopedii pedagogicznej pod redakcją Feliksa Kierskiego (Kierski 1923). Warto zatem odnotować w tym miejscu, że już w 1932 roku w Leksykonie pedagogiki wspótczesnej Niemieckiego Instytutu Nauk Pedagogicznych w Münster pod redakcją Josefa Spielera znalazło się bardzo obszerne hasło autorstwa wybitnego pedagoga zdrowia Linusa Boppa (Buschka, Grimm, Klein 2002), poświęcone zapobiegawczemu, prewencyjnemu wychowaniu (Vorbeugende Erziehung), a w nim koncepcji św. Jana Bosco jako największego mistrza i prekursora pedagogiki prewencyjnej (Bopp 1932, s. 1239-1243). Zaskakujące jest to, że ze współczesnych leksykonów pedagogicznych w Niemczech zupełnie zniknęło pojęcie wychowania prewencyjnego. Jeśli w Kleines Pädagogisches Wörterbuch (Małym słowniku pedagogicznym) 
autorstwa Josefa A. Kellera i Felixa Novaka pojawia się termin „prewencja”, to tylko i wyłącznie w ujęciu medycznym, jako profilaktyka zdrowotna, pedagogika odgrywa tu istotną rolę w uczeniu dzieci i młodzieży zachowań prozdrowotnych, np. unikania palenia, mycia zębów itp. (Keller, Novak 1993, s. 284-285).

Niewątpliwie $\mathrm{z}$ najszerszym omówieniem interesującego nas tematu w pracach leksykograficznych w naszym kraju, obejmującym nie tylko życie, działalność, ale i twórczość pedagogiczną włoskiego wychowawcy, mamy do czynienia w Encyklopedii pedagogicznej XXI wieku pod redakcją Tadeusza Pilcha, w haśle „Bosko Jan, Giovanni Melchiorre Bosco” (Niewęgłowski 2003, s. 422-425). Redaktor encyklopedii, pracując nad doborem i zakresem haseł, w tym także dotyczących powyższego pedagoga, chciał przekazać nauczycielom solidny fundament „wiedzy merytorycznej i humanistycznej do ukształtowania osobowości wszechstronnej, otwartej, innowacyjnej. A co jeszcze ważniejsze, dać motywację do rzetelnego wypełniania powinności wobec samego siebie, wobec młodzieży, wobec społeczeństwa. Wiele w nich historii, bo kto nie zna i nie rozumie przeszłości, ten jest ślepy na przyszłość" (Pilch 2006, s. 10).

Z dostępnych mi zagranicznych leksykonów i encyklopedii pedagogicznych muszę wskazać na wybitnego czeskiego historyka i badacza biografii klasyków pedagogiki z całego świata. Miroslav Cipro zawarł hasło „Bosco Giovanni (18151888)" w swoich dwóch autorskich, a nie zbiorowych wydaniach leksykograficznych. W pierwszej, bardzo syntetycznej edycji klasyków pedagogiki przedstawił obszernie, jak na tego typu publikację, życie włoskiego duchownego, założyciela kongregacji salezjanów, którego system wychowawczy przeniknął w wielu krajach świata nie tylko do katolickiego, ale i świeckiego szkolnictwa, oraz zakorzenił się w nich w unikalnej formie oratoriów jako placówek prewencyjnych (Cipro 2000, s. 62-63). Czeski pedagog przywołał w biogramie dwie, jakże charakterystyczne myśli Don Bosco, które oddają jego swoiste podejście do wychowania, a mianowicie: „Bawcie się, skaczcie, krzyczcie, tylko nie grzeszcie”, i zbliżony do pedagogii Janusza Korczaka apel do wychowawców: „Poszukujcie w swojej działalności duszy, nigdy pieniędzy, jakiejś godności czy stanowiska” (Cipro 200o, s. 63). Dwa lata później poszerzył wspomnianą biografię w sposób znaczący w napisanej przez siebie Encyklopedii źródeł wychowania. Galerii światowych pedagogów (Cipro 2002, s. 242-252). Historyka interesowała nie tylko koncepcja pedagogiczna wychowania prewencyjnego Don Bosco, ale także jej recepcja na ziemiach Czech, Moraw i Słowacji. Jego twórczość i znaczenie w naukach pedagogicznych porównał do takich pedagogów pracujących z młodzieżą jak: Anton Makarenko, Janusz Korczak, David Wills czy August Aichhorn.

\section{Pedagogia św. Jana Bosko w podręcznikach pedagogicznych}

Wydawałoby się, że kiedy współcześni polscy badacze przybliżają myśl i praktykę wychowawczą okresu od II Rzeczypospolitej do ponowoczesności III 
Rzeczypospolitej, to wskazują na ożywienie pedagogiki katolickiej, do którego powinna przyczyniać się także recepcja systemu św. Jana Bosko. Rzeczywiście, w imponującej monografii naukowej ks. Jana Niewęgłowskiego SDB, którą wydało w 2011 roku Towarzystwo Naukowe Franciszka Salezego, jest znakomite studium o konkretnych próbach recepcji myśli i ideałów św. Jana Bosko w wychowawczo-społecznej działalności salezjanów w Polsce od czasu podjęcia przez nich pracy na ziemiach polskich w 1898 roku aż do upadku państwa socjalistycznego w 1989 roku. Autor przedstawia bardzo rzetelnie genezę i rozwój poszczególnych placówek oświatowych i wychowawczych w aspekcie historycznym i pedagogicznym. Zwraca także uwagę „na realizację programów nauczania i wychowania, osiągnięcia edukacyjne wychowanków oraz na pozaszkolne formy pracy z młodzieżą (sport, religia, harcerstwo), charakterystyczne dla domów salezjańskich” (Niewęgłowski 2011, s. 9). To, czego nie podjął się w tym dziele ks. Jan Niewęgłowski, ale też czego robić nie musiał ze względu na klarownie określony przedmiot własnych badań i studiów, to usytuowanie pedagogii św. Jana Bosko w podręcznikach historii myśli pedagogicznej czy syntezach współczesnych nauk o wychowaniu w kraju i na świecie.

W znakomitym akademickim podręczniku teorii i koncepcji wychowania ks. Mariana Nowaka, niezależnie od zaproponowanej przez niego autorskiej propozycji wieloaspektowej teorii wychowania, mamy wielokrotne odniesienia do św. Jana Bosko. Autor ten nie poświęca koncepcji salezjanina odrębnego rozdziału czy podrozdziału, gdyż nie chce ograniczać teorii wychowania do jakiegoś jednego podejścia. Nie zapomina jednak o jego wkładzie w wychowawcze znaczenie i kształtujący wymiar sztuk teatralnych. Jak pisze - doceniając aktualny charakter metody wychowawczej, jaką jest dzisiaj drama - „bardzo zbliżona do dramy jest forma pracy wychowawczej zaproponowanej przez ks. Jana Bosko - to «teatrzyk» (il teatrino), który powinien być jednak skierowany do szerszej publiczności. Nie chciałbym, aby nasze teatrzyki - tu cytuję za J. Bosko - stały się spektaklami publicznymi. Teatrzyk ks. Bosko nie jest narzędziem komunikowania się czy rozwijania talentów, lecz środkiem socjalizacji i wychowania. Stanowił on wartościowe narzędzie wychowania całych grup katolików i obywateli - zarówno w zmieniających się Włoszech, jak i w innych krajach, gdzie pracują Salezjanie. Ta forma oddziaływania sprawdziła się w procesie socjalizacji i inkulturacji, a nade wszystko w przystosowaniu młodych pokoleń do życia w społeczności przedindustrialnej. Nie możemy pominąć wielkiego doświadczenia teatru ks. Jana Bosko w pracy wychowawczej z młodzieżą określaną jako «inna», a była to po prostu młodzież biedna, zaniedbana wychowawczo, z ograniczonymi perspektywami na przyszłość, uciekająca w agresję, nałogi i postawy aspołeczne. Tym młodym ludziom ks. Jan Bosko mówił przez teatrzyk, że są równi z innymi i mają pełne prawo do rozwoju i dostępu do edukacji” (Nowak 2008, s. 417-418).

Podręczniki do pedagogiki III RP albo w ogóle nie zawierają odniesień do pedagogii św. Jana Bosko (Krajewski 2005; Wołoszyn 1998), albo bardzo skromnie odnotowują obecność jego myśli w wychowywaniu młodych pokoleń. 
W przetłumaczonym na język polski tomie Pedagogika. Kluczowe zagadnienia Friedricha W. Krona w rozdziale dotyczącym procesu wychowania pojawia się jako jedno z kluczowych podejść wychowanie rozumiane jako pomoc w życiu albo pomoc w samopomocy dzieciom, chorym i upośledzonym (Kron 2012, s. 162). Niemiecki pedagog wskazuje na św. Jana Bosko jako budujący przykład wcielania w życie idei przeciwstawiania się zjawiskom bezradności, przeżywania kryzysów czy niedostatku, które powodowane są troską o dziecko. „Wychowanie jako pomoc życiowa zaczyna się zwróceniem uwagi na najbardziej oczywiste potrzeby dziecka, włącza w krąg swoich zainteresowań negatywne i pozytywne doświadczenia dzieci i ich poznawcze, afektywne, sensomotoryczne, motywacyjne i moralne czyny i poglądy. Przede wszystkim jednak wychowawca nie stawia się ponad dziećmi, lecz towarzyszy im i wczuwa się w ich problemy. Uczy się patrzeć oczami dziecka albo z jego perspektywy. Tylko w ten sposób znajduje wspólnie z dziećmi rozwiązania i nowe drogi, dzięki którym jego podopieczni stają się coraz bardziej samodzielni. Tak więc punktem wyjścia wychowania jako pomocy życiowej są negatywne pola problemowe, ale nie negatywna antropologia. Negatywna sytuacja dzieci jest traktowana jako okazja do pracy nad jej przezwyciężaniem. Właśnie problemy dzieci stanowią otwartość sytuacji wychowawczej” (Kron 2012, s. 163).

Marian Nowak wyróżnia w kategorii współcześnie kluczowych i najczęściej stosowanuch środków wychowawczych grupę prewencyjnych środków wychowawczych, powołując się na koncepcję Jana Bosko uwzględniania w procesie wychowawczym dzieci i młodzieży środków, które będą służyły „zapobieganiu ewentualnym szkodom, jakie mogłyby dotknąć wychowanka. W takich działaniach chodzi przede wszystkim o wzbudzenie w wychowanku wrażliwości moralnej na to, co nie jest słuszne, i zapobieganie konieczności wymierzania kary. Zaliczamy do nich m.in. usystematyzowane przez św. Jana Bosko w ramach całego systemu prewencyjnego środki: asystencję wychowawczą i oratorium, dobry przykład i autorytet wychowawcy" (Nowak 2008, s. 463-464).

Pedagogika prewencyjna nie znajduje swojego odzwierciedlenia w dwutomowym podręczniku akademickim, jaki ukazał się w XXI wieku. Nie piszą o niej ani Stefan Wołoszyn (Wołoszyn 2003), ani Bogusław Milerski w rozdziale poświęconym pedagogice religii (Milerski 2003), ani też Marian Nowak przy okazji omawiania pedagogiki personalistycznej (Nowak 2003). Koncepcja wychowania św. Jana Bosko została natomiast ujęta w najnowszym, czterotomowym, międzynarodowym podręczniku akademickim pod moją redakcją, w rozdziale poświęconym modelom wychowania. Jego autor, niemiecki pedagog Christian Callo z Monachium, wyodrębnia w rozdziale poświęconym koncepcjom i wyobrażeniom wychowania jego odmiany: wychowanie jako przyciąganie, wychowanie jako przewodzenie, wychowanie jako chów, wychowanie jako pozwolenie na dorastanie, wychowanie jako przystosowanie oraz wychowanie jako pomoc w życiu. To właśnie w tej ostatniej kategorii ulokował myśl i praktykę św. Jana Bosko. Jego zdaniem jest on „pierwszym w historii, który na podstawie wiary chrześcijańskiej domagał się 
pomocy w wychowaniu dla wszystkich ludzi, również dla tych, którzy piętnowani i wykluczeni żyją na marginesie społeczeństwa” (Callo 2006, s. 281).

Oczywiście znacznie łatwiej jest wskazać rozprawy z historii wychowania czy podstaw pedagogiki, w których nawet w bibliografii czy przypisach nie wspomina się św. Jana Bosko jako autora-twórcę dającego się przecież wyodrębnić systemu wychowawczego (Bizon 1920; Chmaj 1963; Kostkiewicz 2013; Kot 1924; Seredyński 1868; Siemieńska 1936), niż dokonać rekonstrukcji syntez, w których zajmuje on czy też powinien zająć poczesne miejsce. Zaskakuje nieobecność jego koncepcji wychowania w najnowszych podręcznikach z zakresu pedagogiki religii (Rogowski 2011), pedagogiki pastoralnej (Mazur 2011), pedagogiki społecznej Kościoła katolickiego (Jusiak 2013) czy pedagogiki nadziei jako pedagogiki o inspiracji chrześcijańskiej (Chrobak 2009). Słabo, powierzchownie jest też przywoływana pedagogia św. Jana Bosko we współczesnych podręcznikach historii wychowania. U Stefana Ignacego Możdżenia nazwisko Bosko nie pojawia się w rozdziale poświęconym głównym kierunkom pedagogicznym, w tym ani w pedagogice chrześcijańskiej XX wieku, ani w katolickiej myśli pedagogicznej w Polsce (1918-1939). Natomiast znajduje się w części dotyczącej szkolnictwa w Polsce w latach 1918-1945, w podrozdziale, który dotyczy zakładów opiekuńczo-wychowawczych. Autor wskazuje tu na zakłady wychowawcze prowadzone przez zgromadzenia zakonne, wśród których „najbardziej zasługiwał na uwagę uprzedzający system wychowania salezjanów św. Jana Bosko i michaelitów ks. Bronisława Markiewicza, które miały za sobą wiele lat doświadczeń. System B. Markiewicza był odmianą systemu J. Bosko, opierał się przede wszystkim na dawaniu dobrego przykładu przez wychowawców, szczerym współżyciu z wychowankami, pogodnej atmosferze rodzinnej” (Możdżeń 200o, s. 130).

Zastosowana przez ks. Czesława Kustrę metoda badań historyczno-pedagogicznych myśli pedagogicznej Bronisława Markiewicza - jako kontynuatora systemu wychowawczego ks. Jana Bosko na ziemiach Polski (także w okresie zaborów) pozwoliła na interesującą, wielopoziomową analizę jej zastosowania w wychowaniu. Ukazane zostało dzięki temu bogactwo stanowiska teoretycznego i możliwości jego aplikacji do najważniejszych wciąż jeszcze środowisk wychowawczych, jakimi są rodzina, Kościół i szkoła. Społeczno-kulturowy i historyczny kontekst badań polskiego nurtu recepcji i oryginalnej rekonstrukcji pedagogii św. Jana Bosko sprawia, że bliski staje się nam nowatorski wkład w dokonania jej twórcy, którego poglądy nie są jeszcze powszechnie znane. Czesław Kustro wpisuje się w charakterystyczny także dla Bogdana Nawroczyńskiego nurt badań komparatystycznych, który polega na poznawaniu rozwoju określonej idei w ustalonym przez badacza okresie. Zastosowanie w pracy perspektywy historycznej ułatwia zrozumienie współczesnej roli wychowania dialogowego, narodowego czy religijnego w polskiej pedagogice przełomu XIX i XX wieku. Otrzymujemy zarazem doskonałe źródło wiedzy o tych nurtach wychowania w sytuacji, gdy w społeczeństwie ponowoczesnym, otwartym 
i demokratycznym mamy do czynienia z pluralizmem idei, zmiennością paradygmatów czy różnorodnością podejść badawczych.

W monografii ks. Czesława Kustry poświęconej Bronisławowi Markiewiczowi znajdziemy wiele przesłań społecznych i religijnych, które zyskują współcześnie szczególny wymiar i aktualność, jak chociażby:

- postulat oparcia porządku społecznego, w tym ludzkiej pracy, na religii, by dzięki doskonaleniu cnoty powściągliwości ludzie młodzi byli zdolni do roztropnego ograniczania wydatków konsumpcyjnych i przeznaczali zaoszczędzone środki na inwestycje we własny warsztat produkcyjny czy przedsiębiorstwo;

- zainteresowanie problemami młodzieży wykluczonej, z marginesu społecznego, a poddanej destruktywnemu wpływowi zdemoralizowanego środowiska;

- podkreślanie walorów religijnego wymiaru samowychowania, doskonalenia własnego charakteru dzięki wyzwalaniu sił duchowych i rozbudzaniu życia wewnętrznego jednostki;

- potrzeba powoływania zrzeszeń o charakterze samopomocowym, kulturalnym, wychowawczym, oświatowym, religijnym itp., które przywróciłyby ludziom pracy należny im prestiż i rangę społeczną, a przede wszystkim wpływ na życie i decyzje gospodarcze, oraz ograniczyłyby omnipotencję biurokracji, administracji i niekompetentnej władzy w gospodarce narodowej, co jest zarazem ewidentnym zaczynem budowania samorządów zawodowych;

- zwrócenie uwagi na siłę i wymiar duchowy kultury narodu w budowaniu jego tożsamości i suwerenności oraz pokoju w świecie (Kustro 2002).

$\mathrm{Z}$ analizy rozpraw Bronisława Markiewicza wyłania się jego wciąż mało znane w pedagogice systematycznej podejście personalistyczne do celów, treści i metod wychowania chrześcijańskiego, które jawi się jako zapowiedź czy może nawet jeden z pierwszych symptomów przygotowywania się polskiej myśli pedagogicznej do wychowania tak w nurcie posoborowym (akcentującego podmiotowość wychowanka i łączącego proces wychowania z samowychowaniem jednostki), jak i w nurcie pedagogiki humanistycznej. Ks. Czesław Kustro odsłania na tle współczesnej wiedzy o wychowaniu prekursorskie rozwiązania ks. Bronisława Markiewicza, które wyrażały się m.in. w:

- poprzedzaniu procesu oddziaływań diagnozą rozwoju wychowanków,

- włączaniu w ten proces metod terapii pedagogicznej i psychologicznej, działań prewencyjnych i profilaktycznych czy

- budowaniu dialogowej, bazującej na wzajemnym zaufaniu atmosfery szacunku i miłości w placówce opiekuńczo-wychowawczej.

Nic nie straciły na aktualności jego poglądy na temat potrzeby, możliwości i zasad budowania prewencyjnego mikrosystemu wychowawczego w ścisłym powiązaniu z innowacyjnym podejściem pedagogów do nieustannej jego optymalizacji. Sformułował przy tym niezwykle istotną przesłankę dla kolejnych pokoleń, 
by tworząc własną koncepcję wychowania czy wzorując się na cudzym modelu lub systemie wychowawczym, nie trzymało się wiernie jego założeń, ale angażowało się „w ten system całą swoją osobowością z wielkim wysiłkiem, pracą nad sobą, większym samokrytycyzmem, w ten sposób przezwyciężając skostniałe formy działania w obliczu nowych, niełatwych do rozwiązania zagadnień" (Kustro 2002, s. 303).

Jest to nie tylko uzasadnieniem odejścia ks. Bronisława Markiewicza od wiernego naśladowania systemu wychowawczego ks. Jana Bosko, ale i zwróceniem uwagi na twórczy charakter roli pedagoga nowatora, który powinien z jednej strony wywierać swoją osobowością piętno na wychowankach, z drugiej zaś liczyć się z uwarunkowaniami społecznymi w realizacji własnego projektu.

Powrócę jednak do dalszej recepcji pedagogii św. Jana Bosko w obecnie dostępnych młodzieży akademickiej i jej nauczycielom podręcznikach historii wychowania. Niestety, Sławomir Sztobryn nie raczył w swojej analizie historii wychowania uwzględnić św. Jana Bosko. Wynika to $\mathrm{z}$ faktu, że prezentuje on w swoich studiach typowy dla czasów PRL-u rzekomo historyczny sceptycyzm, równocześnie ukrywając własną postawę światopoglądową, dzięki czemu zwalnia siebie z naukowego obowiązku zachowania prawdy o badanych czasach, wydarzeniach i ich głównych aktorach. Jak przyznaje: „dyscyplinę naukową tworzą ludzie o określonych światopoglądach, preferencjach metodologicznych i różnych umiejętnościach narracyjnych" (Sztobryn 2006, s. 4).

Tak więc ów historyk wyróżnia wśród badaczy dziejów wychowania i myśli pedagogicznej twórców dyscypliny profesjonalnie uprawiających historię wychowania w Polsce (wymieniając m.in. Ludwika Chmaja) i historyków wychowania wywodzących się ze środowiska nauczycieli gimnazjalnych II RP (np. Władysława Seredyńskiego). Siebie nieskromnie i nie przedstawiając dowodów, zalicza do grona „mniej znanych badaczy, którzy przyczynili się do rozwoju dyscypliny w pierwszej połowie XX wieku” (Sztobryn 2006, s. 5). Przyjmując w prezentacji dziejów wychowania chronologiczno-problemowy układ treści, zapewnia czytelników, że jego uwaga została skoncentrowana na ich filozoficzno-teoretycznej stronie, „ponieważ jednym z czynników decydujących o zmianach w wychowaniu są zmiany w sferze aksjologicznej, a więc w sferze poglądów społecznych typowych dla określonego czasu i kręgu kulturowego" (Sztobryn 2006, s. 5). Jak łatwo jest dostrzec w jego wybiórczym studium całkowitą redukcję pedagogiki i oświaty o korzeniach i inspiracjach chrześcijańskich, że już nie wspomnę o katolickich, które całkowicie pomija! Tak jakby ta pedagogia w ogóle nie istniała. Nie tylko w tym przypadku własne poglądy i „przedsądy” badacza stają się czynnikiem zakłócającym wiarygodność przekazu.

Podobnie uczynił Sławomir Sztobryn w opublikowanym razem z Małgorzatą Świtką tomie źródeł myśli pedagogicznej z lat 1900-1939, któremu nadał miano parergi, powołując się na schopenhauerowskie tłumaczenie tego słowa jako drobnych, małych utworów (Sztobryn, Świtek 2006). Słusznie odczytał dualizm w dziedzinie badań historyczno-pedagogicznych, który wyraża się w dwóch podejściach: albo 
problemowym, albo teoretycznym i praktycznym. W badaniach historycznych zainteresowań naukowców Sztobryn jest zwolennikiem wyraźnego rozdzielenia dotychczasowej względnej jedności historii doktryn i myśli pedagogicznej oraz historii oświaty na zupełnie odrębne subdyscypliny. „Przy okazji uwolnilibyśmy się w jakimś stopniu od nadmiernie rozbudowanego kontekstu politycznego, który z nauki czyni jeden z elementów propagandy, zaniżając jej wartość poznawczą i moralną" (Sztobryn, Świtek 2006, s. 9).

Jego podejście nie jest odkrywcze, powołuje się on bowiem na socjalistycznych pedagogów, takich jak np. Bogdan Suchodolski czy Jan Hellwig. Sam dostrzega nieobecność w studiach historii myśli i doktryn pedagogicznych tekstów pomniejszych przedstawicieli idealistycznej wizji kultury jako obrazu ducha ludzkiego. W tym też ujęciu jest to ciekawy zbiór, chociaż - jak już wspomniałem - nie znalazło się w nim miejsce dla żadnego przedstawiciela pedagogiki personalistycznej nurtu katolickiego, ani też nie ma merytorycznego uzasadnienia dla takiego doboru źródeł poza faktem wybiórczego uwzględniania ich przez współczesnych mu historyków wychowania.

Zamierzony politycznie brak chrześcijańskiej myśli pedagogicznej w podręcznikach historii wychowania okresu PRL-u wypełnia analiza wieku XIX i XX w pracy Jana Drausa i Ryszarda Terleckiego (Draus, Terlecki 2005) oraz w podręczniku poświęconym historii szkolnictwa autorstwa ks. Adama Orczyka (Orczyk 2008). U Drausa i Terleckiego jest wreszcie mowa o wkładzie systemu wychowania prewencyjnego w rozwój nauk pedagogicznych XIX wieku, poświęcono temu zagadnieniu odrębny podrozdział. Jakże mówić dzisiaj o kontynuacji dzieła św. Jana Bosko, gdy nie przywołuje się go w kanonie wiedzy historycznej? Autorzy syntetycznie ujmują istotę systemu wychowania włoskiego duchownego jako oryginalnego i prekursorskiego w zakresie działalności duszpastersko-wychowawczej wśród młodzieży poddanej ekskluzji społecznej. Opisany przez nich sens i sposób podejścia do wychowania młodzieży w czasach, które reprodukują istotę i mechanizmy „wilczego” kapitalizmu, jest niezwykle aktualny.

Ks. Adam Orczyk podobnie, aczkolwiek w znacznie szerszym zakresie, poświęca odrębny podrozdział systemowi prewencyjnemu św. Jana Bosko, kiedy rekonstruuje dzieje szkoły i wychowania w okresie rewolucji przemysłowej. Autor ten nie tylko wprowadza problematykę wychowania religijnego, ale przede wszystkim zwraca uwagę na holistyczne podejście do tego procesu, w którym wychowawcy powinni uwzględniać także inne wymiary życia i potrzeby młodzieży, ,jak troska o mieszkanie, wyżywienie i ubranie, dbałość o rozwój fizyczny, wychowanie intelektualne i moralne, przygotowanie do zawodu, rozrywka i spędzanie czasu wolnego. Uwzględniając potrzeby i oczekiwania młodych, ks. Bosko kładzie nacisk, by w oratoriach panował klimat radości i pogody ducha. Uważał, że pragnienie szczęścia oraz wewnętrzna (duchowa) i zewnętrzna radość nie stoi w sprzeczności z życiem chrześcijańskim, ale wręcz przeciwnie - był przekonany, że tylko religia może dać człowiekowi prawdziwe szczęście” (Orczyk 2008, s. 177-178). 


\section{Miejsce pedagogii św. Jana Bosko na mapie koncepcji i systemów pedagogicznych w świecie}

W ostatnim dwudziestopięcioleciu polska myśl pedagogiczna została wzbogacona o wiele rozpraw naukowych, których twórcy skupili się na swoistym odczytaniu dzieł św. Jana Bosko jako klasyka nauk o wychowaniu. Klasyk pedagogiki to pojęcie dwuznaczne, bowiem dotyczy tej osoby, której „myśl jest ciągle żywa; mimo upływu czasu jest współczesna w tym znaczeniu, że także dzisiaj odwołujemy się do niej, kiedy myślimy o pedagogice i wychowaniu, że więc odgrywa ona rolę autorytetu. Słowo «klasyk» ma zatem pewien sens normatywny, co oznacza, że myśl zawarta w dziele jest dla nas czymś istotnym; bierzemy ją pod uwagę, liczymy się z nią, choćbyśmy nawet nie w pełni się z nią zgadzali" (Folkierska 2005, s. 7). Inny wymiar bycia klasykiem, który można by określić jako temporalny, wiąże się z tym, że w stosunku do dzieł twórcy mamy już odpowiedni dystans na skutek minionych lat. Stwierdzamy wówczas, że jego dzieło przeszło próbę czasu, potwierdzając w ten sposób, że zawiera w sobie coś nieprzemijającego, trwałego, ponadczasowego. Takie dzieło staje się „inspiracją dla współczesnej myśli pedagogicznej, czy też raczej ulega ono [...] obiektywizującej świadomości, której właściwe neutralność i dystans uniemożliwiają dostrzeżenie żywotnego związku dzieła z naszym dzisiejszym doświadczeniem" (Folkierska 2005, s. 9).

Zdaniem Andrei Folkierskiej nadal ma miejsce naiwne odczytywanie teorii pedagogicznej i dokonań, które sprowadza się albo do ich odrzucenia, albo do ich afirmacji, apologetyki. Wówczas „myśl w nich zawartą pojmuje się albo jako bezwzględnie prawdziwą, albo jako bezwzględnie fałszywą, nie podejmując trudu zadania własnego pytania, na które owe dzieła są jedynie pewnymi, zawsze niekoniecznymi odpowiedziami” (Folkierska 2005, s. 25-26). Ten rodzaj recepcji jest najmniej wartościowy naukowo, gdyż „dzieło «aktualizowane» jest martwe dla tych, którzy usiłują pokazać jego aktualność. Martwe jest dlatego, że w owych aktualizacjach traci swój całościowy sens, rozpada się na poszczególne ideologie pedagogiczne bądź na wyspecjalizowane w obrębie pedagogiki dyscypliny naukowe, istniejące obok siebie bez żadnego wzajemnego związku. Tego rodzaju recepcja pokazuje jedynie to, że współczesny badacz [czyjejś - B.Ś.] twórczości [...] «zgadza się» z jego takimi czy innymi poglądami, czy też pojmuje je jako «wkład» w rozwój poszczególnych nauk pedagogicznych" (Folkierska 2005, s. 12). Autor analizowanych rozpraw, wykładów nie musi jednak dążyć do ostatecznego zgłębienia dziedzictwa myśli czy przeprowadzenia wobec czyichś poglądów ostatecznej krytyki, by nas zobowiązać do takiego właśnie sposobu odczytania, ale może procesowi recepcji dzieła nadać charakter otwarty. Aktualizacja myśli pedagogicznej św. Jana Bosko może mieć jeszcze jeden ważny wymiar, a mianowicie - międzynarodowy. Jego prace mają bowiem nie tylko włosko- ale i obcojęzyczne wydania, co jest najlepszym potwierdzeniem ich uniwersalnej wartości, gdyż stają się inspiracją tak dla pedagogiki szkolnej, jak i społecznej. 
Twórca jednej z pierwszych systematyk prądów i kierunków pedagogicznych w Polsce Bogdan Nawroczyński uważał, że do współczesnych prądów można zaliczyć te, które dopiero się tworzą, zaczynają oddziaływać na społeczeństwo i jeszcze nie przeminęły, a ponadto wiążą się z poszczególnymi osobami, obozami czy stronnictwami politycznymi. „Wzbudzają namiętności i najsprzeczniejsze sądy. To nam utrudnia oddzielenie tego, co naprawdę doniosłe, od tego, co nie zdobędzie trwalszego znaczenia, choć na razie jest modne lub cieszy się poparciem możnych protektorów" (Nawroczyński 1987, s. 483). Dzisiaj kategoria współczesności w odniesieniu do prądu myśli humanistycznej oznacza właściwie zerwanie z chronologicznym widzeniem tej kwestii. Polega to na tym, że za współczesne uznaje się nurty myśli pedagogicznej mające długofalowe znaczenie w humanistyce czy - szerzej - w dziejach nauki. Ich przedstawiciele mogli zatem należeć do innej generacji, ale ich twórczość jest niezwykle żywotna, nieustannie aktualna i aktualizowana. Tak, na przykład, zdaniem Andrzeja Misia za filozofię współczesną należałoby uznać „,te koncepcje filozoficzne, które przez dzisiaj żyjącego człowieka mogą być uznane za artykulacje jego wizji świata i człowieka, i które (najczęściej we fragmentach i w zniekształceniu) funkcjonują w naszej świadomości potocznej (przy czym ludzie wyznający określone poglądy, niestety, rzadko kiedy wiedzą, kto je pierwszy sformułował i z jakiego dzieła filozoficznego one pochodzą)" (Miś 2006, s. 10).

O istocie prądów stanowi zdaniem tego pedagoga atrakcyjna siła jakiegoś ideału pedagogicznego oraz ludzie, dla których stał się on naczelną wartością. To oni są najczęściej nośnikami tkwiącego w nim przesłania, „poczynają widzieć całe życie współczesne, wszystkie szczegóły wychowania i nauczania w jego oświetleniu, poczynają też szukać środków najkrótszą drogą wiodących do jego osiągnięcia. [...] Więc tzw. prądy pedagogiczne powstają w związku z zapalaniem się ludzi do nowych celów wychowania. Gdy jednak cel dostatecznie już został ustalony i sprecyzowany, wówczas na plan pierwszy wysuwa się sprawa środków. Powstają różne pomysły, zyskując sobie rzesze zwolenników. Następują zastosowania tych pomysłów w praktyce. Pierwotna myśl ulega przy tym zmianom lub ustępuje miejsca nowej. W ten sposób wytwarzają się również pewne obozy, a nawet prądy pedagogiczne" (Nawroczyński 1987, s. 489-49o).

Przedmiotem refleksji humanisty powinny być nie tylko materiał abstrakcyjno-pojęciowy i procedura wysuwania tez oraz argumentowania za ich trafnością, ale i świadomość dokonywanych wyborów oraz wielości rozwiązań tak samo roszczących sobie prawo do uniwersalności, a więc ubiegających się o rangę prawdy najlepszej. Filozofowanie paradygmatyczne nie może prowadzić do ostatecznych rozstrzygnięć, mimo że może pojawiać się w trakcie taka pokusa, ponieważ filozof stawałby się wtedy funkcjonariuszem ludzkości czy misjonarzem odkrywającym prawdę utajoną. Tymczasem powinien on przyjąć status - jak to określa Stefan Morawski - „notorycznego pasożyta”, maksymalnie samokrytycznego (Morawski 1999), odkrywającego niepewność, ciągły niedosyt tego, co sam formułuje, oraz 
świadomego, że jego wyjaśnianie świata i interpretacja są jednymi z wielu. Musi doświadczać zatem dramatycznej samowiedzy wielu prawd, zdając sobie zarazem sprawę z tego, że będąc niejako skazanym na ekumenizm wielości paradygmatycznej, nie może bronić żadnej z nich (Śliwerski 2009).

W Polsce minionego dwudziestopięciolecia transformacji i wolności badań naukowych wytworzyły się swoiste szkoły czy wspólnoty naukowe skupione wokół wspólnego paradygmatu, wśród których najsilniejsza niewątpliwie jest pedagogika krytyczna i odzyskująca swoją tożsamość oraz rangę pedagogika religii, pedagogika personalistyczna, ale także pedagogika humanistyczna o orientacji niedyrektywnej, antyautorytarnej. Ciekawie eksponuje je w swojej diagnozie Zbigniew Kwieciński, biorąc pod uwagę miniony okres dwudziestolecia III RP, w którym za najważniejsze zmiany uznał: różnorodność wewnętrzną, otwarcie pedagogiki na świat zewnętrzny, nowe szkoły naukowe, rozwój subdyscyplin, obecność naszej dyscypliny w sferze publicznej, rozproszone innowacje edukacyjne, powstanie ogromnej liczby wydawnictw. „Pedagogika polska w ostatnich dwóch dekadach stała się polifoniczna, wielogłosowa, różnorodna teoretycznie, problemowo, metodologicznie i ideologicznie w prowadzonych studiach i badaniach. Jeżeli przypomnimy sobie «mapę paradygmatów», zaproponowaną przez R. Paulstona, która rozpina się w dwóch wymiarach (zmiana - zastój; jednostka, duchowość, kultura - państwo, struktura), to w ostatnim okresie mamy do czynienia z ciągłym wypełnianiem przez pedagogów polskich wszystkich pól tej mapy" (Kwieciński 2011a, s. 15).

Nie przeszkadza to temu, by nadal była uprawiana $z$ dużym powodzeniem pedagogika empiryczna, choć, niestety, eksperymentów pedagogicznych przeprowadza się w niej mniej niż w okresie PRL-u. O ile rzetelnie podchodzący do swoich badań pedagodzy studiują teorie filozoficzne, socjologiczne czy psychologiczne, by właściwie umocować przesłanki swoich sądów i hipotez, o tyle psycholodzy, socjolodzy i filozofowie, zabierając głos na temat edukacji, wychowania czy kształcenia, nadal nie sięgają do naszych rozpraw, ukrywając swój brak predylekcji w tym zakresie. Być może sami jesteśmy temu winni, bo nie zabiegamy o promocję swoich rozpraw, upowszechnianie wyników własnych badań, mimo że spełniają one wysokie standardy metodologiczne. Czyżby zawiść, personalne uprzedzenia, niezdolność wzniesienia się ponad osobiste urazy $\mathrm{z}$ takich czy innych powodów miały nadal pozbawiać pedagogikę miana nauki wnoszącej istotny wkład w wiedzę o kluczowych dla społeczeństwa, państwa, a w niektórych przypadkach i świata zjawiskach?

Jakże trafnie podzieliła się swoim niepokojem o zanik uniwersyteckiej przyjaźni i solidarności naukowców w wyniku zaistniałych w nich przemian Joanna Rutkowiak. Instrumentalizacji wiedzy towarzyszy „wyprzedaż uczonych”. Żeby to chociaż byli uczeni, ale coraz częściej ma się ochotę powtórzyć za tą autorką: „Być głupim i mieć pracę - to jest szczęście” (Rutkowiak 2010, s. 54). Zdanie to określa ludzi ze stopniem lub tytułem naukowym, którzy poddając się logice rynku, bardziej są zorientowani na posiadanie aniżeli na to, by „być”. „Pobyt na uniwersytecie nabiera charakteru akademickiej biznesowej transakcji - w której 
to niemal wyłącznie oczekiwania studenta/konsumenta w zakresie uzyskiwania usług edukacyjnych oraz prawa rynku wyznaczają zakres przekazywanej wiedzy i kwalifikacji" (Melosik 2002, s. 93). W projektowanych przez siebie przypadkach możliwego ewoluowania uniwersytetów od „pustego miejsca”, „przedsiębiorstwa”, uniwersytetu „niszowego”, „masowego” ku uniwersytetowi „elitarnemu”, „oporowemu” czy „minimalnemu” wskazuje na tę jego wersję, która jest już od lat rzeczywistą, a nie potencjalną, a mianowicie na uniwersytet „masowy”. W miejscu przepełnionym studentami z jednej strony, a spauperyzowanymi, rozdartymi w swoich postawach między cynizmem a donkiszoterią nauczycielami akademickimi z drugiej, nie ma już miejsca na wspólnotę uczących się i prowadzących badania. Ci pierwsi bowiem nie są ani należycie przygotowani do pracy umysłowej, gdyż został radykalnie obniżony poziom matury, ani też nie oczekują jakiegokolwiek wysiłku intelektualnego, obowiązków, skoro wszystko w toku studiów ma być lekkie, łatwe i przyjemne, drudzy zaś minimalizują swoją aktywność, co ma usprawiedliwiać „harmonię cyników” nieprzeciwstawiających się wyniszczaniu fundamentów uniwersytetu.

To właśnie Bogdan Nawroczyński wskazywał w swoich komparatystycznych studiach, że chcąc zrozumieć myśli pedagogiczne dawnych klasyków, trzeba nieustannie sięgać głęboko w wiek poprzedni (Nawroczyński 1987). Podjęcie zatem badań nad polską tradycją pedagogiczną w obszarze systemu wychowawczego św. Jana Bosko staje się zarazem zaproszeniem do nadania badaniom pedagogicznym także takiego charakteru, by dzięki nim odnaleźć zakorzenienie treściowe i formalne, a nie tylko instytucjonalne tej koncepcji wychowania w szeroko rozumianej humanistyce i wywodzących się z niej naukach pedagogicznych. Jakże ważne jest w tym zakresie osadzenie myśli pedagogicznej ks. Jana Bosko na tle głównych kierunków teoretycznych i praktycznych polskiej pedagogiki od XIX wieku do pierwszej dekady XXI wieku, by nie zniknęła ona spośród aktualnych podejść do wychowania. Przed współczesnymi pedagogami staje poważne wyzwanie mocniejszego i lepiej uargumentowanego usytuowania pedagogii Jana Bosko wśród wielości doktryn, koncepcji, systemów czy teoretycznych podejść do wychowania. „Skoro wychowanie i myśl pedagogiczna tak ściśle są związane z poszczególnymi narodami i państwami, nasuwa się pytanie, czy w ogóle można mówić o współczesnych prądach pedagogicznych na jakimś terytorium światowym, w każdym razie znacznie przekraczającym granice poszczególnych państw i narodów. Niewątpliwie tak! Wiele bowiem zrodzonych w określonych warunkach odrywa się niejako od nich, przekracza najdalsze granice, dociera wszędzie, gdzie człowiek kulturalny interesuje się sprawami wychowania, ma - jednym słowem - obieg światowy" (Nawroczyński 1987, s. 486). Nie jest to łatwe w sytuacji, gdy w wyniku amerykanizacji sposobu uznawania dyscyplin za stricte naukowe, wyłączy się z nich nauki humanistyczne i społeczne, w tym także pedagogiczne.

Powinniśmy zatem podjąć kolejne badania, które pozwoliłyby ulokować pedagogię św. Jana Bosko na mapach (w systematykach, typologiach) współczesnych 
prądów i kierunków myśli pedagogicznej. Nikt bowiem dotychczas tego nie zrobił. Jest to tym bardziej zasadne, że pedagogika nie jest wyjątkiem wśród pokrewnych sobie nauk społecznych, jak psychologia czy socjologia, których koniec jako nauk był już zapowiadany wielokrotnie zarówno przez wielu ich przedstawicieli, jak i oponentów. Jak słusznie pisze Teresa Hejnicka-Bezwińska: „Ogłaszanie "końców...» ma długą tradycję. Zapowiedź końca mamy już w Biblii. Zainteresowanie owymi «końcami...» w pewnych okresach historycznych zdecydowanie wzrasta, a wiąże się to zwykle z wydarzeniami mającymi traumatogenny charakter. Falowanie tego zainteresowania można by rozpatrywać w kategoriach mody. Jeżeli jednak punktem zainteresowania czynimy pedagogikę, to należy ten problem rozpatrywać w kontekście idei i ideologii kształtujących określoną formację intelektualną ludzi, odpowiedzialną za zmianę kulturową" (Hejnicka-Bezwińska 2009, s. 11).

Bydgoska profesor opowiada się za tym ostatnim powodem ogłaszania końca pedagogiki jako nauki, powołując się na tezy o końcu historii i końcu człowieka Francisa Fukuyamy oraz idee upadku wielkich narracji według Michela Foucaulta, które pozwalają na doszukiwanie się końca pedagogiki jako dyscypliny naukowej niebędącej w stanie w ponowoczesnym świecie dalej uprawomocniać określonej wizji wiedzy i edukacji człowieka na skutek dekonstrukcji i rozbicia ,jednolitej dotąd wizji świata na nieskończoną wielość gier językowych i kontekstualny charakter wszelkich prawd" (Hejnicka-Bezwińska 2009, s. 14). Trudno się z tym nie zgodzić, choć wiemy, że zjawisko rewolucji naukowych i zmiany w ich wyniku paradygmatów dotyczy wszystkich dziedzin wiedzy, także nauk ścisłych. Dlaczego zatem pedagogika, określana bardzo szeroko jako wiedza o wychowaniu i kształceniu człowieka, miałaby się ostać jako ostatnia z nauk humanistycznych i społecznych?

Biorąc pod uwagę funkcje pedagogiki wobec praktyki edukacyjnej, Zbigniew Kwieciński stawia pytanie: co płynie w głównym nurcie pedagogiki, a co na jego poboczach, i czy ta wiedza wraz z refleksją pedagogiczną jest wykorzystywana przez wychowawców? Co właściwie jest nośnikiem trwałych i powtarzalnych wzorów kształcenia, wychowania i oświaty jako podsystemu społecznego (Kwieciński 2005, s. 67)? „Nazwijmy wprost te dominujące nurty: jest to pedagogia wdrażania do przemocy i posłuszeństwa, wsparta na żądzy władzy, na libidalnej dominacji (nazwana wtórnie pedagogiką tradycyjną, konserwatywną, pozytywistyczną, obiektywistyczną, didaskalocentryczną, esencjalistyczną, etatystyczną, socjalistyczną itp.), albo pedagogia zachęcająca do indywidualnej pomyślności, wsparta na żądzy posiadania, na libidalnej chciwości (nazwana pedagogiką Nowego Wychowania, humanistyczną, indywidualistyczną, pajdocentryczną, postępowo-liberalną). Współcześnie mieszczański etos skrzętnego bogacenia się przekształcił się w nakaz używania, radosnej konsumpcji, zabawy, karnawalizacji, zwany postmodernizmem czy ponowoczesnością" (Kwieciński 2005, s. 68).

Biorąc pod uwagę kryterium światopoglądowe i nastawienia emocjonalno-motywacyjne, sytuuje Kwieciński wobec tych pedagogii nurty poboczne, jak: „pedagogie przewrotne, jawnie kontestujące, opozycyjne, przekorne i odwracające 
wobec tych pierwszych, oraz pedagogie odlotowe, proponujące różne utopijne, nierealne na początku ideologie, które z czasem, drążąc powszechną świadomość i praktykę, dokonują znacznych przekształceń edukacji powszechnej. W obrębie tego «marginesu» światopoglądowego umieszczam też pedagogie pokrętne, jawnie w swych intencjach cyniczne, oszukańcze, antyedukacyjne, choć zasłaniające się fasadą pięknych i chwytliwych haseł, ale wsparte mocno na zimnych, a nieraz brudnych interesach i chciwości ich realizatorów" (Kwieciński 2005, s. 71). Źródeł dominującego w praktyce oświatowej wzoru pedagogii autor ten doszukuje się poza edukacją. To właśnie na „marginesie epistemologicznym”, a więc na poboczu pedagogiki naukowej, rozwijają się pedagogie potoczne i dyskretne, po które sięgają politycy czy szeroko rozumiani klienci rynkowej oferty.

Schemat 1. Pedagogie pokrętne, przewrotne, oboczne wobec głównego nurtu

$\begin{array}{ccc}\begin{array}{c}\text { Pokrętne } \\ \text { (antyedukacyjne) }\end{array} & \begin{array}{c}\text { Przewrotne } \\ \text { (opozycyjne) }\end{array} & \begin{array}{c}\text { Odlotowe } \\ \text { (ideologiczne) }\end{array} \\ & \begin{array}{c}\text { Naukowe } \\ \text { Analityczne (herm., empir.) } \\ \text { Pozytywne (ded., dośw.) } \\ \text { Krytyczne } \\ \text { (demask., transform.) }\end{array}\end{array}$
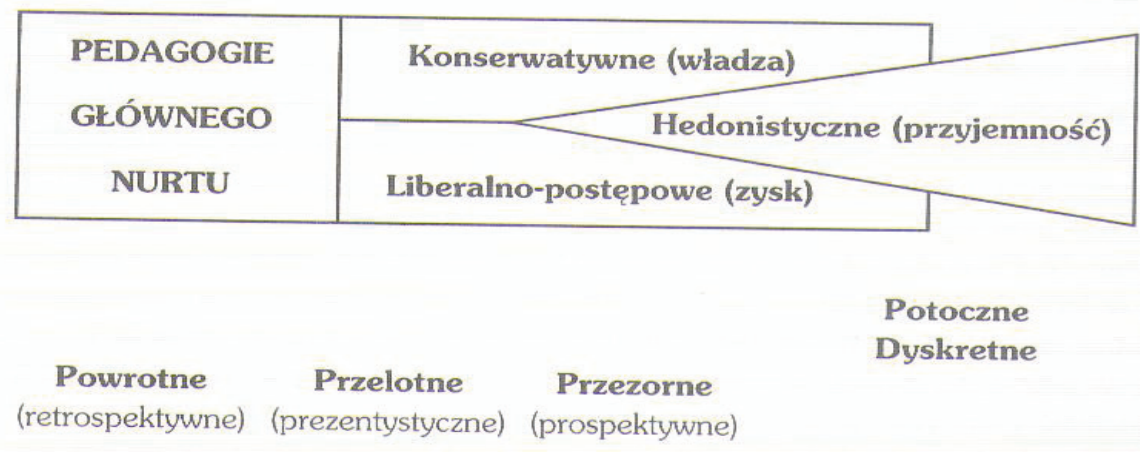

Kryterium temporalne

Schemat 1. Pedagogie przekorne, oboczne wobec głównego nurtu

Źródto: opracowanie własne

źródło: Z. Kwieciński 2005, s. 69

Czy system prewencyjnego wychowania św. Jana Bosko ma się znajdować wśród wyróżnionych przez Zbigniewa Kwiecińskiego pedagogii perswazyjno-patetycznych, pedagogii nawiedzonych (teonomicznych), folkowych, esencjalistycznych, pedagogii utraconych nadziei, pedagogii konwersji czy może pedagogii holistycznych 
(Kwieciński 2011b)? W próbie syntetycznego zarysu na tle powszechnych nurtów nauk pedagogicznych pedagogia prewencyjna św. Jana Bosko została usytuowana przez Stefana Wołoszyna w grupie wielkich nurtów teoretycznych, w tym pedagogiki psychologicznej, a w niej w katolickiej pedagogice opiekuńczej nurtu Nowego Wychowania (Wołoszyn 1998, s. 42). Czy rzeczywiście także dzisiaj lokowalibyśmy tę pedagogię w tym nurcie?

Wydany w Polsce przekład podręcznika pedagogiki Heinza-Hermanna Krügera jest jednym z wielu przykładów na to, jak znakomicie rozwinęła się pedagogika jako nauka teoretyczna, a nawet metateoretyczna, o której on sam pisze następująco: „Niejeden czytelnik może się wystraszyć i postawić pytanie, dlaczego ma się zajmować teoriami pedagogicznymi czy jeszcze bardziej skomplikowanie brzmiącą teorią nauki. Teoria nauki jako teoria o teoriach nauk o wychowaniu zajmuje się różnymi szkołami i stanowiskami tej dyscypliny. Krótko mówiąc, chodzi o leżące u podłoża wzorce naukowego myślenia i działania” (Krüger 2005, s. 10). Jest to zatem znakomita syntetyczna i krytyczna analiza teoretycznych koncepcji i stanowisk w naukach o wychowaniu oraz najnowszych podejść metodologicznych we współczesnej pedagogice niemieckiej (Gutek 2003; Krüger 2005; Śliwerski 1998; Śliwerski 2009; Wołoszyn 1998). Heinz-Hermann Krüger słusznie wyszedł z założenia, że badanie różnych kierunków teoretycznych w pedagogice powinno dotyczyć podstawowych wzorów myślenia naukowego i badań naukowych, a przy tym sprzyjać rozpoznawaniu przesłanek teoretycznych pedagogów i ich własnej orientacji badawczej w tym zakresie. Zaproponował podział kierunków w naukach o wychowaniu na dwa podstawowe prądy - pedagogikę kultury (duchową), rozwijającą się od czasu Republiki Weimarskiej aż do początku lat siedemdziesiątych XX wieku, oraz na zapoczątkowaną przez Auguste’a Comte’a i rozwijającą się intensywnie do połowy lat sześćdziesiątych XX wieku pedagogikę empiryczną. Pozostałe kierunki i koncepcje pedagogiczne egzemplifikuje poglądami współczesnych im przedstawicieli oraz tworzących się w epoce ponowoczesnej szkół naukowych.

Natomiast w dalszej części swoich analiz podejmuje zagadnienia związane z metodologią badań w naukach o wychowaniu, ukazując w jej ramach m.in. wciąż jeszcze słabo rozwiniętą w Polsce rolę i zasady prowadzenia badań hermeneutycznych, a także podstawowe cechy i kryteria prowadzenia badań empirycznych. W stosunku do jakościowej i ilościowej orientacji badawczej rysuje stan istniejącej wobec nich krytyki, ale i perspektywy ich dalszego rozwoju. Podejście Heinza-Hermanna Krügera do pedagogiki skłania nas do refleksji nad współczesną systematyką jej prądów i kierunków, uświadamiając nam zarazem, że żadna z istniejących klasyfikacji nie jest ani ostateczna, ani wyczerpująca. Każda jednak pozwala zrozumieć obce typologie wiedzy o wychowaniu i jej interpretacje, co wcale nie musi wiązać się z przyjęciem wobec którejkolwiek z nich postawy akceptującej. Warto także dostrzec przy tej okazji, że przyjęty przez Krügera sposób pisania o kierunkach pedagogicznych w Niemczech ukazuje jego indywidualne odczytania, które zachęcają nas do krytyki, do bronienia różnic, ale i do dialogu czy ponadnarodowego 
dyskursu. W żadnym z krajów nie wypracowano takiej systematyki teorii pedagogicznych, która mogłaby stać się powszechnie obowiązującą. Można jednak dzięki takiej rozprawie wyraźnie dostrzec w rodzimej literaturze przedmiotu klasyfikacje, mapy, modele czy propozycje, które ujmują najważniejsze nurty, kierunki, prądy i ideologie wychowawcze (Śliwerski 2009).

Ks. Marian Nowak uważa, że zanegowanie pedagogiki jako nauki jest w naszym kraju pochodną ciągłego jeszcze myślenia o niej w kategoriach ideologicznej dyscypliny okresu komunistycznego, a więc nie tylko jako pozbawionej autonomii, ale i podlegającej politycznym manipulacjom czy naciskom. „W tej sytuacji, a także przy docierającym do Polski stylu uprawiania pedagogiki krytycznej, stosunkowo łatwo było zmarginalizować pedagogikę w życiu społecznym i w dyskusjach naukowych, a nawet altrove (tu i tam) głosić upadek czy wręcz śmierć pedagogiki” (Nowak 2010, s. 9). Reorientacja prowadzonych w pedagogice badań w kierunku interdyscyplinarnym, wieloparadygmatycznym, otwartym na różnice, ale zarazem wykorzystującym utrwalone już i uznane przez międzynarodową społeczność uczonych metodologie badań nauk społecznych i humanistycznych, sprawiła, że pedagogika zaczęła nie tylko nadrabiać zaległości w stosunku do ich rozwoju, ale i odzyskiwać miano nauki integralnej. Jak pisze Adam Grobler: „badania interdyscyplinarne bywają ożywcze i inspirujące dla poszczególnych subdyscyplin. Tym bardziej badania prawdziwie interdyscyplinarne mogą pomóc w przełamywaniu skostniałych paradygmatów dyscyplin i poszerzaniu ich horyzontów" (Grobler 2010, s. 38).

Najlepszym dowodem na to, że polską pedagogikę stać na włączanie się w badania interdyscyplinarne, jest seria rozpraw pod wspólnym tytułem Wychowanie. Pojęcia. Procesy. Konteksty (Dudzikowa, Czerpaniak-Walczak 2007-2010), jak i podejmowanie badań o charakterze intersubdyscyplinarnym (intradyscyplinarnym), o czym świadczą zmiany i przewartościowania w obszarze zarówno dydaktyki, jak i pedagogiki szkolnej czy pedagogiki specjalnej (Klus-Stańska 2010; Krause 2010). Zachęca do tego podejścia Lech Witkowski, który uważa, że naukowcy nie powinni okopywać się w ramach własnej jedynie dyscypliny naukowej, ale muszą otwierać się na „tropy nienależące wcześniej do ich kanonu czy paradygmatu” oraz wychodzić poza obszar własnej dyscypliny bez poczucia niższości czy wyższości w stosunku do innych nauk, wynikającego z perspektywy własnego wykształcenia. Nawet najwybitniejsi przedstawiciele subdyscyplin pedagogicznych powinni otwierać się „na całość humanistyki w poszukiwaniu impulsów rewitalizujących dyskurs, czyli przywracających mu niezbędną energię i potencjał znaczenia. Mimo że wiele (sub)dyscyplin ulega autodegradacji i swoistemu manieryzmowi ich lokalnych koryfeuszy, to wrażliwość epistemologiczna wręcz zmusza ich do reagowania na bodźce z zewnątrz, czyli po prostu uczenia się z innych pól” (Witkowski 2010, s. 58).

Kiedy warunki wychowania i rzeczywistość wychowawcza budzą szereg wątpliwości, pedagodzy, aby je wyjaśnić, zwracają się z pytaniami do nauk podstawowych, a mianowicie do psychologii (np. Jak ludzie się uczą? Jak postrzegają świat? 
Jak motywują się do uczenia?), do filozofii (Kim jest człowiek? Dlaczego powinien być wychowywany i kształcony?) i do socjologii (W jakim społeczeństwie żyjemy? Czego należy się uczyć dla przyszłości? Jakie struktury utrudniają uczenie się? Jacy „ukryci wychowawcy”, np. środki masowego przekazu, grupy rówieśnicze, reklama itp., utrudniają oddziaływania wychowawcze?). Doskonale zdajemy sobie sprawę z tego, że właśnie w pedagogice podejście interdyscyplinarne jest konieczne, gdyż rozwiązywanie problemów dydaktycznych, wychowawczych czy opiekuńczych wymaga wykorzystywania wiedzy z różnych nauk, by prowadząc analizę interesujących nas zjawisk, wydarzeń czy procesów, które są złożone, wielowymiarowe i trudno uchwytne, zbadać je i zintegrować ze sobą na podstawie wiedzy o nich z wielu nauk. Jak pisze Piotr Oleś: „chcąc wyjaśniać problemy rozwojowe i zaburzenia zachowania w szkole, z pewnością warto sięgnąć do teorii wychowania i medycyny, nie poprzestając na samej psychologii” (Oleś 2010, s. 44).

Pedagogika, jako nauka integrująca wiedzę z innych nauk, także badających wychowanie, kształcenie czy opiekę, musi jednak wystrzegać się, żeby podejścia interdyscyplinarnego nie zastąpił pozorujący je eklektyzm metodologiczny, czyli bezrefleksyjne, pozbawione jakichkolwiek kryteriów metanaukowych łączenie ze sobą wiedzy o badanym zjawisku $\mathrm{z}$ innych nauk, pomijające leżące u ich podłoża (często wykluczające się) teorie i przesłanki. „Inną pułapką «interdyscyplinarnego myślenia» są nieuprawnione uogólnienia, które nie korespondują ani z uzyskanymi wynikami, ani z teorią, na gruncie której są interpretowane” (Oleś 2010, s. 46). Podobnie podchodzą do znaczenia i wartości badań interdyscyplinarnych socjolodzy, dla których są one „synonimem otwartości, podatności na nowe idee, odwagi intelektualnej, wychodzenia poza skostniałe w danej dyscyplinie, nieefektywne wzory działalności naukowej. Interdyscyplinarność w wyodrębnionym, drugim, mocniejszym rozumieniu to sposób dotarcia do złożoności, której nie są w stanie uchwycić wyspecjalizowane, sztucznie podzielone i wyodrębnione dyscypliny i subdyscypliny. Interdyscyplinarność jest więc ostatecznie wyrazem krytyki obecnego stanu nauki i dążenia do jego zmiany" (Tarkowska 2010, s. 53).

W wysoko rozwiniętych gospodarczo krajach świata pedagogika jest traktowana z szacunkiem, jako odrębna i w pełni uznawana nauka. W jednej z najmłodszych dyscyplin naukowych, jaką jest lingwistyka tekstu, która rozwija się od ćwierćwiecza w szeroko pojmowanej interdyscyplinarnej nauce o tekście (Textwissenschaft), zachodnioeuropejscy humaniści dostrzegają także znaczącą i równoważną innym dyscyplinom (retoryce, teologii, jurysprudencji, psychologii, literaturoznawstwu, lingwistyce tekstu) obecność pedagogiki. W prowadzonych przez pedagogów badaniach podstawowych przedmiotem analizy są między innymi występujące w tekstach regularności, które decydują o ich tekstualności (Vater 2009). 
Schemat 2. Klasyfikacja nauk o tekście

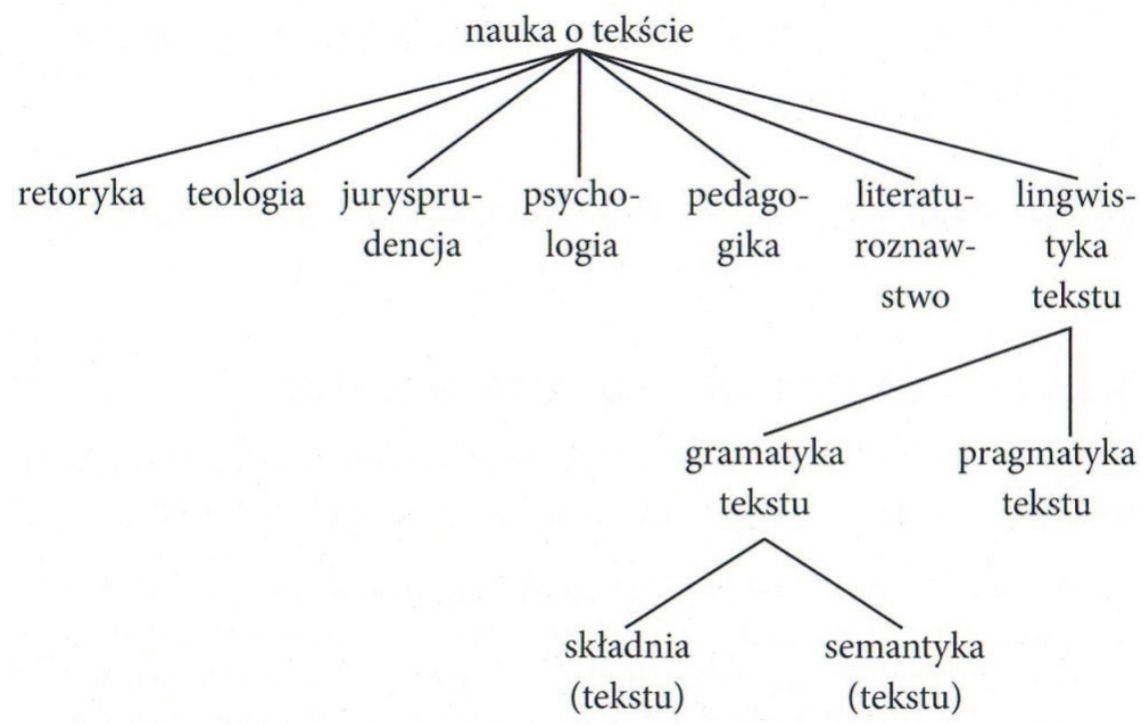

źródło: H. Vater 2009, s. 14

W pedagogice od szeregu lat zwraca się uwagę na to, które jej teksty spełniają kryteria naukowości, a które powinny być traktowane jako nienaukowe. Rozprawy teoretyczne ze swej istoty muszą spełniać kryteria kohezji, koherencji, intencjonalności, akceptowalności, informatywności, sytuacyjności i intertekstualności, natomiast rozprawy empiryczne zawierają poprzedzające konceptualizację badań studia teoretyczne, które są opisem i uzasadnieniem sformułowanego problemu badawczego, jak też stanowią podstawę do zdefiniowania i zoperacjonalizowania zmiennych. W humanistyce i naukach społecznych nie można bazować na traktowaniu dyscyplin naukowych jako rozwijających się jedynie dzięki kumulatywnemu rozwojowi wiedzy i uzyskiwaniu powszechnej zgody co do podstawowych problemów i metod badawczych. Pojawiają się bowiem w nauce anomalie, których nie potrafią wyjaśnić istniejące teorie, prowadzi to do rewolucji naukowych.

To właśnie w wyniku odrzucenia dotychczasowego paradygmatu badawczego i ukonstytuowania nowej tradycji badawczej oraz stylu badań dochodzi do zmian, które naruszają tradycję i generują nowe podejścia badawcze. Tym samym pojawia się nowy paradygmat uprawiania nauki, który określany jest mianem: „nauki postakademickiej” (J. Ziman), „potrójnej helisy” (H. Etzkowitz i L. Leydesdorff), „technonauki” (B. Latour), „nauki postnormalnej” (P. Weingart), „nauki dla zwykłych ludzi” (grassroots science, T. Hansen), „akademickiego kapitalizmu” (S. Slaughter i L. Leslie). Różnice między wymienionymi koncepcjami nie mają jedynie charakteru terminologicznego, ale także merytoryczny (Lekka-Kowalik 2010, s. 79). Skoro tak jest, to uczyńmy wszystko, by w naukach pedagogicznych zaistniała z jeszcze 
większą aktualnością pedagogika normalna św. Jana Bosko, bo uprzedzająca także wszelkie postpedagogie.

\section{Bibliografia}

Bizon S. (1920). Historja wychowania. Podręcznik pedagogiczny dla użytku seminariów nauczycielskich, nauczycieli i ludzi zajmujących się wychowaniem. Warszawa: Wydawnictwo „Globus”.

Bopp L. (1932). Vorbeugende Erziehung. W: Spieler J. Lexikon der Pädagogik der Gegenwart. Freiburg im Breisgau: Herder \& Co.

Buschka M., Grimm R., Klein F. (red.). (2002). Lebensbilder bedeutender Heilpädagoginnen und Heilpädagogen des 20. Jahrhunderts. München: Ernst Reinhardt.

Callo M. (2006). Modele wychowania, tłum. Natoniewska K. W: Śliwerski B. (red.). Pedagogika. Podstawy nauk o wychowaniu. T. 1. Gdańsk: GWP.

Chmaj L. (1963). Prądy i kierunki w pedagogice XX wieku. Warszawa: PZWS.

Chrobak S. (2009). Podstawy pedagogiki nadziei. Warszawa: Wydawnictwo UKSW.

Cipro M. (2002). Encyklopedie prameny výchovy. Galerie svĕtových pedagogů. Druhý svazek. Devatenácté století. Praha: nakładem własnym.

Cipro M. (200o). Slovník pedagogů. Praha: nakładem własnym.

Draus J., Terlecki R. (2005). Historia wychowania. Wiek XIX i XX. Kraków: Wydawnictwo WAM, WSF-P „Ignatianum”.

Dudzikowa M., Czerepaniak-Walczak M. (red.). (2007-2010). Wychowanie. Pojęcia. Procesy. Konteksty. T. 1-5. Gdańsk: GWP.

Folkierska A. (2005). Sergiusz Hessen - pedagog odpowiedzialny. Warszawa: Wydawnictwa Uniwersytetu Warszawskiego.

Grobler A. (2010). Interdyscyplinarność. „Rocznik Pedagogiczny”, nr 33.

Gutek G.L. (2003). Filozoficzne i ideologiczne podstawy edukacji, tłum. Kacmajor A., Sulak A. Gdańsk: GWP.

Hejnicka-Bezwińska T. (2009). Kontekst pytania o „koniec pedagogiki jako nauki”, „Edukacja”, nr 4.

Jusiak R. (2013). Pedagogika społeczna Kościoła katolickiego. Lublin: Wydawnictwo KUL.

Keller J.A., Novak F. (1993). Prävention. W: Kleines Pädagogisches Wörterbuch. Grundbegriffe, Praxis-orientierungen, Reformideen. Freiburg: Verlag Herder.

Kierski F. (red.). (1923). Podręczna encyklopedia pedagogiczna. Lwów: Książnica Polska Tow. Nauczycieli Szkół Wyższych.

Klus-Stańska D. (2010). Dydaktyka wobec chaosu pojęć i zdarzeń. Warszawa: Wydawnictwo Akademickie „Żak”.

Kostkiewicz J. (2013). Kierunki i koncepcje pedagogiki katolickiej w Polsce 1918-1939. Kraków: Oficyna Wydawnicza „Impuls”. 
Kot S. (2005). Historja wychowania. Zarys podręcznikowy. Warszawa: Nakład Gebethnera i Wolffa.

Krajewski M. (2005). Dzieje wychowania i doktryn pedagogicznych. Zarys wykładu. Płock: Wydawnictwo Naukowe „Novum”.

Krause A. (2010). Współczesne paradygmaty pedagogiki specjalnej. Kraków: Oficyna Wydawnicza „Impuls”.

Kron F.W. (2012). Pedagogika. Kluczowe zagadnienia. Podręcznik akademicki. Pojęcia. Procesy. Modele, tłum. Cieślik E. Sopot: GWP.

Krüger H.-H. (2005). Wprowadzenie w teorie i metody badawcze nauk o wychowaniu, tłum. Sztobryn D., wstęp i oprac. Śliwerski B. Gdańsk: GWP.

Kupisiewicz C., Wojnar I. (red.). (1996). Myśliciele - o wychowaniu. Warszawa: Oficyna Wydawnicza BGW.

Kupisiewicz C., Kupisiewicz M. (2009). Słownik pedagogiczny. Warszawa: Wydawnictwo Naukowe PWN.

Kustro C. (2002). Powściagliwość i praca w wychowaniu człowieka. Współczesne odczytanie koncepcji opiekuńczo-wychowawczej ks. Bronisława Markiewicza (1842-1912). Toruń: Wydawnictwo Uniwersytetu Mikołaja Kopernika.

Kwieciński Z. (2005). Pedagogie przekorne wobec pedagogii głównych nurtów. Problem. Model. Zachęta do dyskusji. W: Hejnicka-Bezwińska T., Leppert R. (red.). Ewolucja „ogólności” w dyskursach pedagogicznych. Bydgoszcz: Wydawnictwo Uniwersytetu Kazimierza Wielkiego.

Kwieciński Z. (2011a). Pedagogika po przejściach - aspekty pozytywne. W: Nowak-Dziemianowicz M., Rudnicki P. (red.). Pedagogika. Zakorzenienie i transgresja. Wrocław: WN DSW.

Kwieciński Z. (2011b). Problem pedagogii nurtów głównych i pobocznych. W: Jaworska-Witkowska M., Kwieciński Z. Nurty pedagogii. Naukowe, dyskretne, odlotowe. Kraków: Oficyna Wydawnicza „Impuls”.

Lekka-Kowalik A. (2010). Nauka jako zawód i powołanie - sto lat po analizach Maxa Webera. W: Walczak M. (red.). Metodologia: tradycja i perspektywy. Lublin: Wydawnictwo KUL.

Mazur P. (2011). Podstawy pedagogiki pastoralnej. Kraków: WSF-P „Ignatianum”, Wydawnictwo WAM.

Melosik Z. (2002). Uniwersytet i społeczeństwo. Dyskursy wolności, wiedzy i władzy. Poznań: Wydawnictwo Wolumin.

Milerski B., Śliwerski B. (red.). (200o). Pedagogika. Leksykon PWN. Warszawa: WN PWN.

Milerski B. (2003). Pedagogika religii. W: Kwieciński Z., Śliwerski B. (red.). Pedagogika. Podręcznik akademicki. T. 1. Warszawa: Wydawnictwo Naukowe PWN.

Misiaszek K. (2012). Pedagogia salezjanów (Towarzystwa św. Franciszka Salezego). W: Kostkiewicz J. (red.). Pedagogie katolickich zgromadzeń zakonnych. Historia i współczesność. T. 1. Kraków: Oficyna Wydawnicza „Impuls”. 
Miś B. (2006). Filozofia współczesna. Główne nurty. Warszawa: Wydawnictwo Naukowe „Scholar”.

Morawski S. (1999). Niewdzięczne rysowanie mapy... O postmodernie(izmie) i kryzysie kultury. Toruń: Wydawnictwo UMK.

Możdżeń S.J. (2000). Historia wychowania 1918-1945. Kielce: Wydawnictwo Stachurski.

Nawroczyński B. (1987). Współczesne prądy pedagogiczne. W: Nawroczyński B. Dzieła wybrane. T. 1. Wybór, przedmowa i wstęp Mońka-Stanikowa A. Warszawa: WSiP.

Niewęgłowski J. (2003). Bosko Jan, Giovanni Melchiorre Bosco. W: Encyklopedia pedagogiczna XXI wieku. T. 1. Warszawa: Wydawnictwo Akademickie „Żak”.

Niewęgłowski J. (2011). Wychowawczo-społeczna działalność salezjanów w Polsce w latach 1898-1989. Warszawa: Towarzystwo Naukowe Franciszka Salezego.

Nowak M. (2003) Pedagogika personalistyczna. W: Kwieciński Z., Śliwerski B. (red.). Pedagogika. Podręcznik akademicki. T. 1. Warszawa: WN PWN.

Nowak M. (2010). Pedagogika - próba zarysowania stanu, perspektyw i kierunków współczesnej polskiej myśli pedagogicznej. „Rocznik Pedagogiczny”, nr 33.

Nowak M. (2008). Teorie i koncepcje wychowania. Warszawa: WAiP.

Okoń W. (2004). Nowy słownik pedagogiczny. Warszawa: Wydawnictwo Akademickie „Żak”.

Oleś P. (2010). Interdyscyplinarność - wyzwanie i konieczność. „Rocznik Pedagogiczny", nr 33.

Orczyk A. (2008). Zarys historii szkolnictwa i myśli pedagogicznej. Warszawa: Wydawnictwo Akademickie „Żak”.

Pilch T. (red.). (2006). Encyklopedia pedagogiczna XXI wieku. Warszawa: Wydawnictwo Akademickie „Żak”.

Pilch T. (red.). (2006). Słowo wstępne. W: Encyklopedia pedagogiczna XXI wieku. Warszawa: Wydawnictwo Akademickie „Żak”.

Pomykało W. (red.). (1997). Encyklopedia pedagogiczna. Warszawa: Fundacja Innowacja.

Rogowski C. (2007). Leksykon pedagogiki religii. Podstawy - koncepcje - perspektywy. Warszawa: Wydawnictwo Księży Werbistów.

Rogowski C. (2011). Pedagogika religii. Podręcznik akademicki. Toruń: Wydawnictwo Adam Marszałek.

Rutkowiak J. (2010). O tęsknocie do uniwersyteckiej przyjaźni: przemiany w uniwersytecie, przemiany w jego ludziach. „Teraźniejszość - Człowiek - Edukacja”, nr 3.

Seredyński W. (1868). Pedagogia polska w zarysie. Lwów: Nakładem Karola Wilda w Poznaniu i M. Leitgebera.

Siemieńska L. (1936). Główne kierunki współczesnej pedagogiki. Pedagogika katolicka w świetle badań Fr. Hovre’a. Lwów: Księgarnia „Książka” A. Mazzucato.

Sztobryn S. (2006). Historia wychowania. W: Śliwerski B. Pedagogika. Podstawy nauk o wychowaniu. T. 1. Gdańsk: GWP. 
Sztobryn S., Świtka M. (red.). (2006). Polskie badania nad myślą pedagogiczna w latach 1900-1939. Parerga. Gdańsk: GWP.

Sztobryn S. (2006). Wstęp. W: Sztobryn S., Świtka M. (red.). Polskie badania nad myślą pedagogiczną w latach 1900-1939. Parerga. Gdańsk: GWP.

Śliwerski B. (2009). Współczesna myśl pedagogiczna. Znaczenia, klasyfikacje, badania. Kraków: Oficyna Wydawnicza „Impuls”.

Śliwerski B. (1998). Współczesne teorie i nurty wychowania. Kraków: Oficyna Wydawnicza „Impuls”.

Tarkowska E. (2010). Interdyscyplinarność i socjologia. „Rocznik Pedagogiczny”, nr 33.

Vater H. (2009). Wstęp do lingwistyki tekstu. Struktura i rozumienie tekstu, tłum. Błachut E., Gołębiowski A. Wrocław: Oficyna Wydawnicza ATUT.

Witkowski L. (2010). Uwagi o interdyscyplinarności w pedagogice (Z perspektywy epistemologii krytycznej). „Rocznik Pedagogiczny”, nr 33.

Wołoszyn S. (1998). Nauki o wychowaniu w Polsce w XX wieku. Próba syntetycznego zarysu na tle powszechnym. Kielce: Dom Wydawniczy „Strzelec”.

Wołoszyn S. (2003). Rozwój i zmienność wychowania i kształcenia. W: Kwieciński Z., Śliwerski B. (red.). Pedagogika. Podręcznik akademicki. T. 1. Warszawa: WN PWN.

Wołoszyn S. (wybór i opr.). (1998). Źródła do dziejów wychowania i myśli pedagogicznej. T. 1-3. Kielce: Dom Wydawniczy „Strzelec”.

Wrońska H. (2012). Pedagogia salezjanek (Zgromadzenia Córek Maryi Współzałożycielki). W: Kostkiewicz J. (red.). Pedagogie katolickich zgromadzeń zakonnych. Historia i współczesność. T. 1. Kraków: Oficyna Wydawnicza „Impuls”.

\title{
ROLE OF JOHN BOSCO'S PREVENTIVE SYSTEM OF EDUCATION IN THE MODERN TAXONOMY OF EDUCATIONAL THOUGHT
}

\begin{abstract}
The subject of my analysis is the role of John Bosco's educational system in the modern taxonomy of educational thought and in the lexicography of educational science. I do not deal with the reception and updating of Bosco's educational system in the framework of Catholic education since that is a task for priests, sisters, and directly associated lay academics. Those affirming this educational system should be aware of the extent to which this - in my opinion - still undervalued approach to education, which has not only not lost its relevance but which far surpassed its epoch and is present, reinterpreted, marginalized, or distorted. Particularly educators of Christian thought, and of Catholic education especially, are obligated, on the one hand, to cultivate it in their own environments and as well as, on the other hand, to enter it into current classifications, typologies, lexicons,
\end{abstract}


and practical solutions. Although John Bosco preventive system dates back nearly two centuries, it is only now, in post-modern capitalism, that it can become one of the most effective approaches to working with persons being excluded, already excluded, or threatened with social exclusion.

Key words: Christian education, religious education, Catholic education, educational system, social exclusion, prevention, socialization, anticipatory education, streetworking, pedagogical lexicography, pedagogical biographistics

Bogusław Śliwerski - pedagog, profesor zwyczajny Uniwersytetu Łódzkiego i Akademii Pedagogiki Specjalnej im. Marii Grzegorzewskiej w Warszawie; przewodniczący Komitetu Nauk Pedagogicznych PAN. Ostatnie publikacje: „Edukacja (w) polityce. Polityka (w) edukacji” (2015), „Diagnoza uspołecznienia publicznego szkolnictwa III RP w gorsecie centralizmu" (2013). Adres e-mail: boguslaw.sliwerski@uni.lodz.pl. 